ENGINEERING CHANGE NOTICE

1. ECN 644467

Page 1 of 2

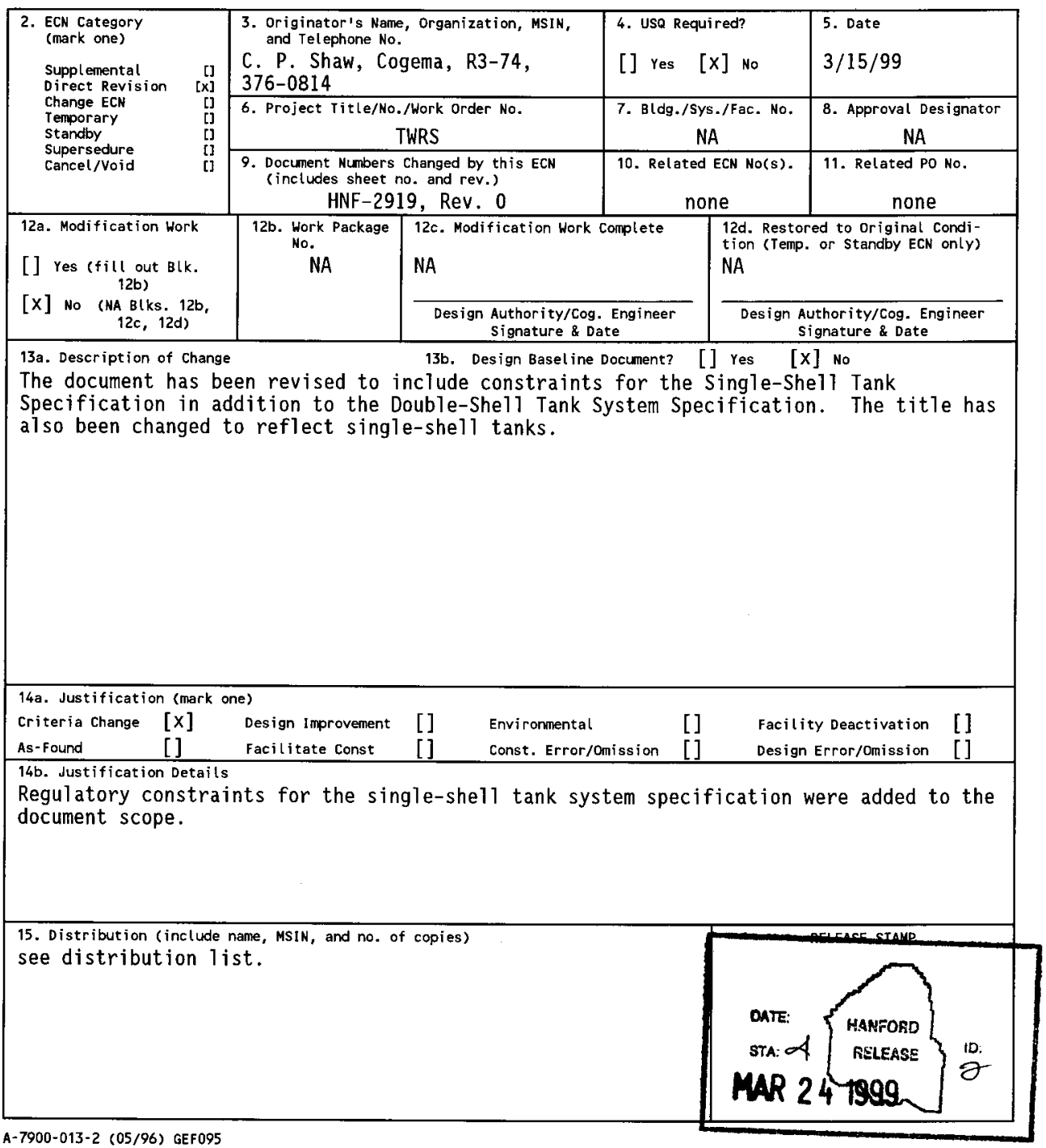




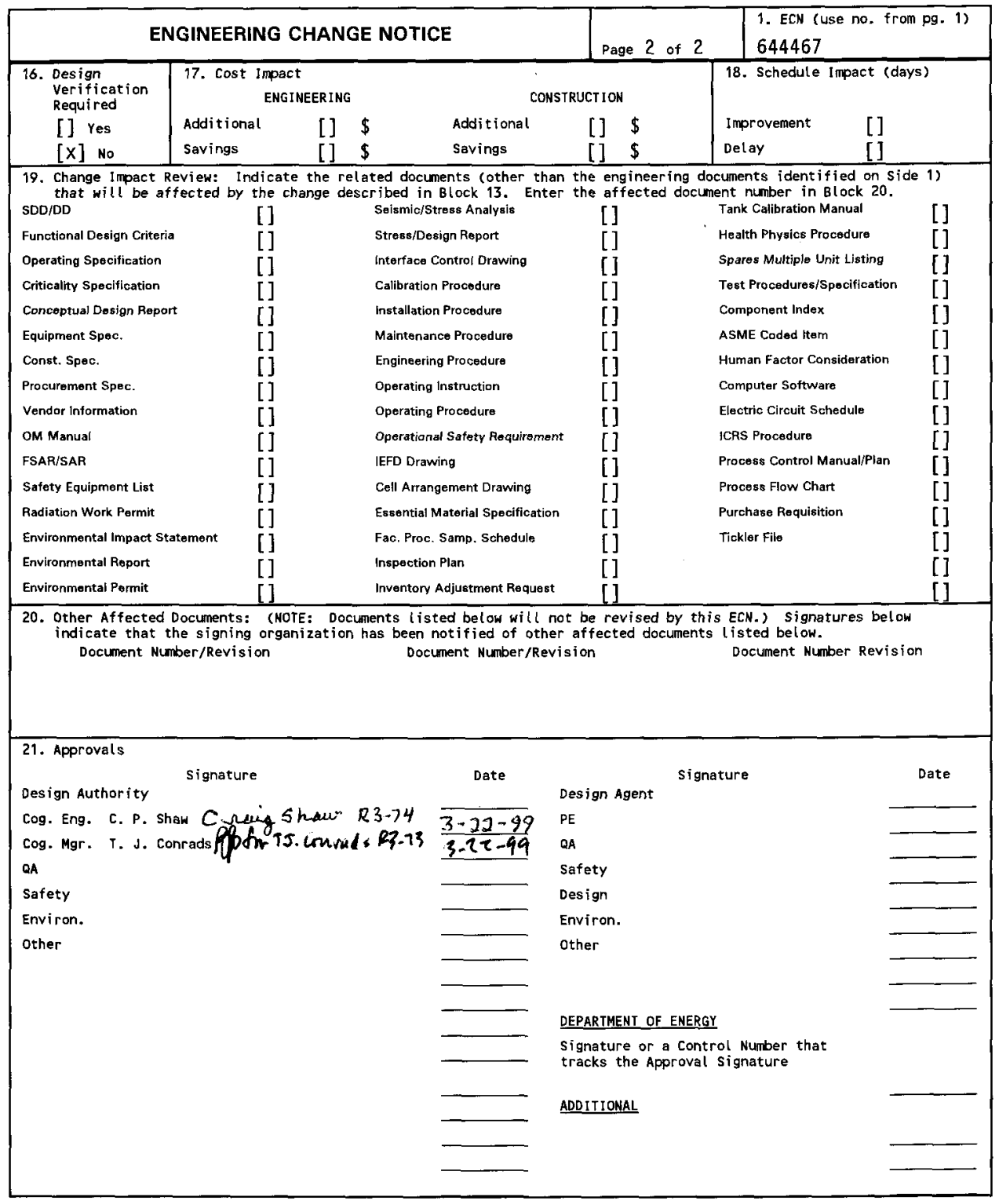




\title{
Constraints for System Specifications for the Double-Shell and Single-Shell Tank Systems
}

\author{
C. P. Shaw \\ Cogema Engineering Corporation, Richland, WA 99352 \\ U.S. Department of Energy Contract DE-AC06-96RL13200
EDT/ECN: $644467 \quad$ UC: 721
Org Code: Charge Code: 106462/106464 \\ B\&R Code: Total Pages: 33
}

Key Words: double-shell tanks, single-shell tanks, regulatory requirements, systems engineering

Abstract: This is a supporting document for the Level 1 Double-Shell and Single-Shell System Specifications. The rationale for selection of specific regulatory constraining documents cited in the two system specifications is provided. Many of the regulations have been implemented by the Project Hanford Management Contract procedures (HNF-PROS) and as such as noted and traced back to their origins in State and Federal regulations.

TRADEMARK DISCLAIMER. Reference herein to any specific commercial product, process, or service by trade name, trademark, manufacturer, or otherwise, does not necessarily constitute or imply its endorsement, recomendation, or favoring by the United States Goverment or any agency thereof or its contractors or subcontractors.

Printed in the United States of America. To abtain copies of this document, contact: Document Control Services, P.0. Box 950, Mailstop H6-08, Richland WA 99352, Phone (509) 372-2420; Fax (509) 376-4989.
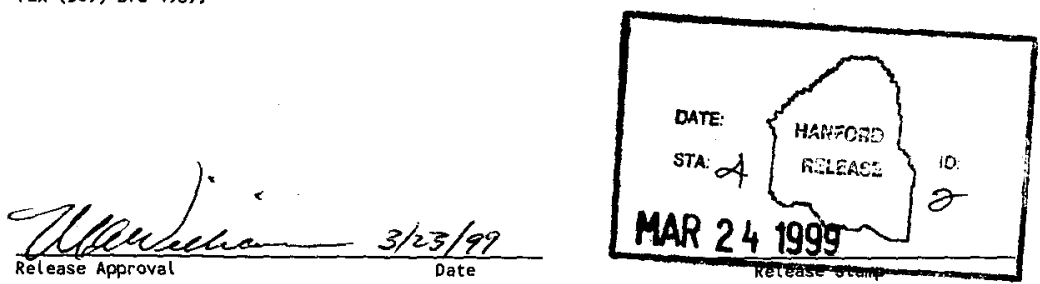

Approved for Public Release 


\begin{tabular}{|c|c|c|c|c|}
\hline \multicolumn{3}{|c|}{ RECORD OF REVISION } & $\begin{array}{l}\text { (1) Document Number } \\
\text { HNF-2919 Rev } 1\end{array}$ & $v 1$ \\
\hline \multicolumn{5}{|c|}{$\begin{array}{l}\text { (2) Title } \\
\text { Constraints for System Specifications for the Double-She1l and Single-She1l Tank } \\
\text { Systems }\end{array}$} \\
\hline \multirow{2}{*}{ (3) Revision } & \multirow{2}{*}{\multicolumn{2}{|c|}{$\begin{array}{l}\text { CHANGE CONTROL RECORO } \\
\text { (4) Description of Change - Replace, Add, and Delete Pages }\end{array}$}} & \multirow{2}{*}{\multicolumn{2}{|c|}{ Authorized for Release }} \\
\hline & & & & \\
\hline 1 RS & & $\begin{array}{l}\text { This document has been revised per ECN } \\
644467 \text { to include constraints for the } \\
\text { Single-Shell Tank Specification in } \\
\text { addition to the Double-Shell Tank } \\
\text { System Specifcation. The title has } \\
\text { also been changed to reflect the } \\
\text { single-shell tanks. The former title } \\
\text { was References for HNF-SD-WM-TDR-007, } \\
\text { "System Specification for the Double- } \\
\text { Shell Tank System: HNF-PR0S. CFRs. DOE } \\
\text { Orders. WACs" and was initially } \\
\text { released as Revision } 0 \text { on EDT 625230, } \\
\text { 7/30/98. }\end{array}$ & 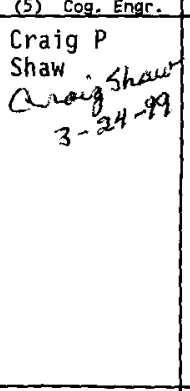 & $\begin{array}{l}\text { (6) Cog. Mgr. Date } \\
\text { Thomas J conrads } \\
\text { Ph for T.J.Courads }\end{array}$ \\
\hline & & & & \\
\hline & & & & \\
\hline & & & & \\
\hline & & & & \\
\hline & & & & \\
\hline & & & & \\
\hline & & & & \\
\hline & & & & \\
\hline & & & & \\
\hline & & & & \\
\hline & & & & \\
\hline & & & & \\
\hline & & & & \\
\hline & & & & \\
\hline & & & & \\
\hline & & & & \\
\hline & & & & \\
\hline & & & & \\
\hline & & & & \\
\hline & & & & \\
\hline & & & & \\
\hline & & & & \\
\hline & & & & \\
\hline & & & & \\
\hline & & & & \\
\hline
\end{tabular}


HNF-2919

Revision 1

\title{
CONSTRAINTS FOR SYSTEM SPECIFICATIONS FOR THE DOUBLE-SHELL AND SINGLE-SHELL TANK SYSTEMS
}

\author{
March 1999 \\ C. P. Shaw \\ Cogema Engineering Corporation \\ Richland, Washington \\ Prepared for \\ U.S. Department of Energy \\ Richland, Washington
}


HNF-2919

Revision 1

This page intentionally left blank. 
HNF-2919

Revision 1

\section{CONTENTS}

1.0 INTRODUCTION

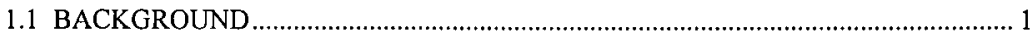

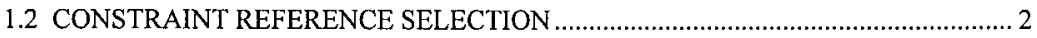

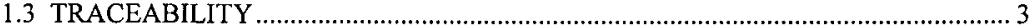

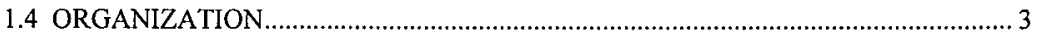

2.0 DOUBLE-SHELL AND SINGLE-SHELL TANK SPECIFICATIONS …......................... 5

\section{APPENDIXES}
A - TRACEABILITY
B - MEETING MINUTES--LEAK-RELATED REQUIREMENTS 
HNF-2919

Revision 1

\section{LIST OF TERMS}

CERCLA Comprehensive Environmental Response, Compensation, and Liability Act, as amended

CFR

Code of Federal Regulations

DST Specification

System Specification for the Double-Shell Tank System, HNF-SD-WMTRD-007

DOE

U.S. Department of Energy

Ecology

Washington State Department of Ecology

EPA

U.S. Environmental Protection Agency

HNF-PRO

Project Hanford Management Contract procedure

HSRCM

Hanford Site Radiological Control Manual

MAR

Mission Analysis Report

NOC

Notice of Construction

PHMC

Project Hanford Management Contract

RCRA

Resource Conservation and Recovery Act of 1976

SARIS

http://sarisweb.pnl.gov/saris/saris.htm

SST

Single-shell tank

TWRS

Tank Waste Remediation System

Tri-Party Agreement

Hanford Federal Facility Agreement and Consent Order

WAC

Washington Administrative Code 
HNF-2919

Revision 1

\section{CONSTRAINTS FOR SYSTEM SPECIFICATION FOR THE \\ DOUBLE-SHELL AND SINGLE-SHELL TANK SYSTEMS}

\subsection{INTRODUCTION}

System Specification for the Double-Shell Tank System, HNF-SD-WM-TRD-007 (Grenard 1997) and System Specification for the Single-Shell Tank System (to be published as HNF 3912) define the requirements for these two systems during their Phase 1 Privatization mission. Many of the sections in these specifications reference legally constraining documents ("constraints") for design guidance and requirements. Referenced documents include U.S. Department of Energy (DOE) Orders, Washington Administrative Codes (WAC), Code of Federal Regulations (CFR), Resource Conservation and Recovery Act of 1976 (RCRA), Hanford Federal Facility Agreement and Consent Order (Tri-Party Agreement) (Ecology et al 1994), and the Project Hanford Management Contract (PHMC) procedures (HNF-PROs). This document provides rationale for the selection/inclusion of constraining documents that impose requirements.

\subsection{BACKGROUND}

The double-shell tank (DST) system is relatively new and consistent with current design and construction standards for radiological, environmental, and worker safety. For the most part, the DST system is also readily adaptable to corrections where needed to achieve and maintain a compliant system. Therefore, this specification assumes that the existing DST system, as well as any modifications to the DST system, will be compliant with all applicable standards for design and construction.

The single-shell tank (SST) system was designed and built before many existing standards were promulgated for radiological, environmental, and worker safety, and its age and condition limits the extent of upgrades and corrections that can occur. In recognition of this, the responsible approval authorities (e.g., DOE, U.S. Environmental Protection Agency [EPA], Washington State Department of Ecology [Ecology]) have generally agreed (see, for example, the Tri-Party Agreement and site-wide RCRA dangerous waste permit) that full-scale retrofitting of the SST system to achieve compliance is not a high priority relative to other Hanford activities. Consequently, there may be differences in how design and construction standards are applied to new versus existing systems, structures, and components of the SST system.

This specification identifies all standards for design and construction that would typically be applicable to the SST system. It has been assumed to be possible, and in most cases desirable, to design and build new elements of the SST system to comply with the applicable standards identified in this specification. It has also been assumed that compliance with the applicable standards will be the initial basis for evaluating the adequacy of (and need to upgrade) the 
existing SST system. However, this specification expects that the responsible approval authorities will need to assess and balance the costs and benefits of various compliance alternatives for the SST system. As a result, the final design and construction specifications for existing elements of the SST system may be the result of extensive negotiations, and thus cannot be definitively identified at this time.

\subsection{CONSTRAINT REFERENCE SELECTION}

Discussion of the origin/traceability of constraints used in various sections of the DST System and SST System Specifications is included. Some sections in the DST and SST Specifications reference HNF-PROs for constraints, other sections in the DST and SST Specifications do not use HNF-PROs but directly reference higher level sources like DOE Orders, WAC, RCRA, Tri-Party Agreement, and CFR, and two sections use the Hanford Site Radiological Control Manual (HSRCM). The design requirements references cited in this document are recommended for use in the DST and SST Specifications.

This selection of HNF-PROs is a "snapshot in time" because the HNF-PROs are still evolving. In the future, HNF-PROs may be issued that can replace the higher level references cited in the DST and SST Specifications, three more have been added since the first release of this document. HNF-PROs implement higher order documents, set consistent interpretation on site, and help resolve conflicts among higher order documents.

The constraints listed in the DST and SST Specifications were selected on the basis of the technical requirements information provided, rather than their programmatic guidance. The principal exception to the process of using technical requirements is addressed in those sections of the SST specification that may be subject to negotiation and agreement with the responsible regulatory agencies. PHMC Contract, Part 1 obliges DST and SST work be conducted in conformance with the Tri-Party Agreement, including applicable RCRA standards.

The DOE, the U.S. Environmental Protection Agency Region 10 (EPA), and Ecology have entered into the Hanford Federal Facility Agreement and Consent Order, referred to as the Tri-Party Agreement to ensure compliance with the Resource Conservation and Recovery Act (RCRA) and the Comprehensive Environmental Response, Compensation, and Liability Act, as amended (CERCLA). The Tri-Party Agreement sets forth certain requirements and milestones for cleanup activities at the Hanford Site. The Contractor agrees to plan and perform the work under this contract in accordance with DOE direction concerning implementation of the Tri-Party Agreement and achievement of current and future milestones in the TriParty Agreement. (H.4, Tri-Party Agreement)

Fluor Daniel Hanford/Lockheed Martin Hanford Subcontract No. 8023764-9-K001, Part III, Clause 16, paragraph (a) mandates the use of HNF-PROs. HNF-PROs were the 
HNF-2919

Revision 1

constraint references of choice if one could be found that provided the necessary requirements; if not, higher level references were selected. References that provide only programmatic, administrative, and management guidance are not appropriate for the DST and SST Specifications sections that need technical design requirements. The HNF-PROs used in the DST and SST specifications were reviewed for utility to the particular section.

\subsection{TRACEABILITY}

To show compliance with contractual requirements, the requirements in the HNF-PROs used in the DST and SST Specifications must be traceable to the DOE orders specified in the PHMC contract, WACs, and CFRs. Appendix A traces HNF-PROs to the Tank Waste Remediation System (TWRS) Mission Analysis Report (MAR) and/or PHMC Contract and subsequently to the external requirements. This trace was done electronically using "http://sarisweb.pnl.gov/saris/saris.htm" (SARIS) and the HNF-PRO search function.

Hard copies of the selected HNF-PROs were reviewed to ensure traceability of requirements to a particular section in the DST and SST Specifications. Likewise, each of the selected WACs, CFRs, and DOE Orders were read for applicability to specific sections of the DST Specification. Many additional HNF-PROs were reviewed for use in the DST and SST Specifications and found not to be an acceptable reference.

\subsection{ORGANIZATION}

This document is organized by the particular DST and SST specification sections in ascending numeric order; only those sections of the specification dealing with regulatory requirements are included. The proposed quotation of each section appears in italics. Following this quote, if used, the cited HNF-PROs are listed along with a listing of the higher level references found in each HNF-PRO. Only higher level references (i.e. WACs, CFRs, DOE orders) for each HNF-PRO are listed; other HNF-PROs, letters, handbooks, etc., were not included. The selected HNF-PROs often contain many more references than are needed to provide a link to the PHMC Contract and the references cited in the MAR. A comment/suggestion is included. There are no technical constraint requirements referencing HNF-PROs, DOE Orders, WACs, or CFRs in DST and SST specifications sections numbered lower than 3.2.6.1. 
HNF-2919

Revision 1

This page intentionally left blank. 
HNF-2919

Revision 1

\subsection{DOUBLE-SHELL AND SINGLE-SHELL TANK SPECIFICATIONS}

\section{DST and SST Specification Section 3.2.6.1, Natural Environments}

The system shall be designed for the natural environmental conditions specified in WHC-SD-GN-ER-50I Rev. I-A, and to withstand the wind, lightning, earthquake, ashfall, and combination loads per HNF-PRO-097 Rev.0. HNF-PRO-097 Rev.0 will take precedence over WHC-SD-GN-ER-501, if conflicts occur.

Comments/Suggestions

Good reference - ties to DOE 5480.28 that is in the PHMC contract.

HNF-PRO-097, Rev.0, Design and Evaluation. -Higher Level References:

DOE/TIC 11268

DOE- RL "HPS-SDC4.1"

DOE-STD-1021-92

DOE 5480.23

DOE 5480.28

DOE 5481.1B

DOE 6430.1A

DOE/EP 0108

DOE-STD-1020

DOE-STD-1023

WAC 296 PART N
A Manual for the Prediction of Blast and Fragment Loading on Structures

Hanford Plant Standard, Standard Design Criteria 4.1, "Design Loads"

Natural Phenomena Hazards Performance Categorization for Structures, Systems and Components.

Nuclear Safety Analysis Reports Natural Phenomena Hazards Mitigation

Safety Analysis and Review System General Design Criteria Standard for Fire Protection of DOE Electronic Computer/Data Processing Systems

Natural Phenomena Hazards Design Evaluation Criteria for DOE Facilities

Natural Phenomena Hazards Assessment Criteria

Department of Labor and Industries

\section{DST and SST Specification Section 3.2.7, Transportability}

Assemblies and components shall be designed to be handled, packaged, marked, and transported in accordance with 49CFR 174, 49 CFR 176, 49 CFR 177.

Comments/Suggestions

The intent of this section is to prevent design of hardware so massive that existing bridges, roads, underpasses etc. can not accommodate its transport. Radioactive or hazardous material transport is covered in Section 3.5.2. This section refers to 49CFR174 Carriage by Rail, 
HNF-2919

Revision 1

49CFR176 Carriage by Vessel, 49CFR177 Carriage by Public Highway. No suitable HNF-PRO was found.

\section{DST and SST Specification Section 3.2.8, Flexibility and Expansion}

The system shall comply with the flexibility and expansion requirements of DOE 6430.1A,0110-3 Division 1 .

Comments: No HNF-PRO addresses flexibility and expansion.

\section{DST and SST Specification Section 3.3, Design and Construction}

The system design shall follow the general design guidelines provided in DOE Order 6430.1A those derived via the RCRA permitting process and such other guidelines as may be authorized pursuant to the Tri-Party Agreement (refer to Introduction for more discussion).

Comments/Suggestions: No HNF-PRO has been identified that addresses this design and construction area or the requirement to meet RCRA requirements and to meet the Tri-Party Agreement.

\section{DST and SST Specification Section 3.3.1.1, Toxic Products and Formulations}

The system shall comply with the requirements of HNF-PRO-45I Rev.0, Regulated Substance Management.

Comments/Suggestions: This HNF-PRO gives the designer direction how to deal with regulated substances and how to possibly avoid their use.

HNF-PRO-451, Rev. 0, Regulated Substance Management -Higher Level References-

29CFR 1910

29CFR1926

40CFR 112

40CFR 165

40CFR247

$40 \mathrm{CFR} 280$

40CFR61

40CFR720

40CFR761

40CFR763

49CFR 171

49CFR 172

DOE 6430.1A
Occupational Safety and Health Standards

Safety and Health Regulation for Construction

Oil Pollution Prevention

Pesticide Use and Control

Toxic Substance Control Act

Storage Tanks

Asbestos

Toxic Substance Control Act

Polychlorinated Biphenyls

Asbestos

Asbestos

Asbestos

General Design Criteria 
HNF-2919

Revision 1

WAC 16-228

Pesticide Use and Control

WAC $16-230$

Pesticide Use and Control

WAC $16-231$

Pesticide Use and Control

WAC $16-232$

Pesticide Use and Control

WAC $173-300$

Dangerous Wastes

WAC $173-340$

Storage Tanks

WAC $173-360$

Storage Tanks

WAC 296-65

Asbestos

\section{DST Specification Section 3.3.1.2, Dangerous Waste}

The system shall incorporate dangerous waste storage and treatment design features that comply with the requirements of WAC 173-303.

Comment: No HNF-PRO has been identified that addresses the broad scope of dangerous waste design issues as well as WAC 173-303. Other sections in the specifications cite more specific parts of WAC 173-303, (xxx). This is an umbrella citation to emphasize the importance of WAC 173-303.

\section{SST Specification Section 3.3.1.2, Dangerous Waste}

The new and modified portions of the system shall incorporate dangerous waste storage and treatment design features that comply with the requirements of WAC 173-303. Existing portions of the SST system are subject to the RCRA negotiation and approval process and relevant agreements pursuant to the Tri-Party Agreement.

Comment: No HNF-PRO has been identified that addresses the broad scope of dangerous waste design issues as well as WAC 173-303. Other sections in the specifications cite more specific parts of WAC 173-303, (xxx); this is an umbrella citation to emphasize the importance of WAC 173-303.

\section{DST Specification Section 3.3.1.3, Decontamination and Decommissioning}

The system shall be designed for ease of decontamination during operation and for decommissioning at the end of system life in accordance with DOE 6430.1A, Sections 011099.0.1, 0205-2, and 1300-11.

Comment: No HNF-PRO has been identified that addresses this area and gives detailed instructions to the designer.

\section{SST Specification Section 3.3.1.3, Decontamination and Decommissioning}

The new and modified portions of systems shall be designed for ease of decontamination during operation and for decommissioning at the end of system life in accordance with DOE 6430.1A, Sections 0110-99.0.1, 0205-2, and 1300-11. Existing portions of the SST system are 
HNF-2919

Revision 1

subject to the RCRA negotiation and approval process and relevant agreements pursuant to the Tri-Party Agreement.

Comment: No HNF-PRO has been identified that addresses this area and gives detailed instructions to the designer.

\section{DST and SST Specification Section 3.3.2, Electromagnetic Radiation}

The system shall comply with electromagnetic radiation emission requirements set forth in HNF-2962, (DRAFT) List of EM Radiation Requirement Standards.

Comments/Suggestions: No HNF-PRO or higher-level reference has been identified that gathers the needed information for design guidance; therefore a Hanford document on the subject has been developed.

\section{DST and SST Specification Section 3.3.3, Nameplates and Product Markings}

The system nameplates and marking shall comply with the requirements of WHC-IP-0842, Vol. IV, Section 4.14.

Comments/Suggestions: No suitable HNF-PRO has been identified.

\section{DST and SST Specification Section 3.3.6.1.1, Occupational Radiological Protection}

The system shall be designed to protect workers from occupational radiation exposures in accordance with the requirements contained in DOE/RL-96-109 Rev0.

Comment/suggestion: DOE/RL-96-109, Rev 0, is also known as HSRCM-1, Hanford Site Radiological Control Manual.

\section{DST and SST Specification Section 3.3.6.1.2, Occupational Safety and Health Administration (OSHA) Standards}

The system shall incorporate occupational safety and health design features that comply with the requirements of WHC-SD-WM-HSP-002, Rev. 3.

Comment: WHC-SD-WM-HSP-002 Rev 3, Tanks Farms Health and Safety Plan derives its authority from 29CFR 1910 (OSHA) per the PHMC Contract.

\section{DST Specification Section 3.3.6.2.1, Corrosion Prevention and Control}

The system shall incorporate corrosion prevention and control features in accordance with WAC 173-303-640(3) and DOE Order 5820.2A Ch 1, Sec 3.b.(2)(g). 
HNF-2919

Revision 1

Comment/suggestion: No HNF-PROs were found that deal with corrosion protection at the detailed level needed for design guidance.

\section{SST Specification Section 3.3.6.2.1, Corrosion Prevention and Control}

The new and modified portions of the system shall incorporate corrosion prevention and control features in accordance with WAC 173-303-640(3) and DOE Order 5820.2A Ch 1, Sec 3.b.(2) (g). Existing portions of the SST system are subject to the RCRA negotiation and approval process and relevant agreements pursuant to the Tri-Party Agreement.

Comment/suggestion: No HNF-PROs were found that deal with corrosion protection at the detailed level needed for design guidance.

\section{DST and SST Specification Section 3.3.6.2.6, Fire Protection}

The system shall meet fire protection design requirements as defined in HNF-PRO-349 Rev.0 Fire Protection Design Criteria.

Comment/suggestion: This is a very good reference that specifies using mandatory design criteria found in DOE Orders, CFRs, WACs, and national consensus standards.

\section{DST Specification Section 3.3.6.3.1, Secondary Containment and Leak Detection}

The system shall incorporate secondary containment and leak detection design features in accordance with 40CFR264.193 and; WAC 173-360 (for underground petroleum tanks only); and WAC 173-303-640(4).

Comments: No HNF-PROs were found that specifically address leak detection at the level of detail needed for design.

\section{SST Specification Section 3.3.6.3.1, Secondary Containment and Leak Detection}

The new and modified portions of the system shall incorporate secondary containment and leak detection design features in accordance with 40CFR264.193; WAC 173-360 (for underground petroleum tanks only); and WAC 173-303-640(4). Existing portions of the SST system are subject to the RCRA negotiation and approval process and relevant agreements pursuant to the Tri-Party Agreement.

Comments: No HNF-PROs were found that specifically address leak detection at the level of detail needed for design. Until the RCRA negotiation and approval process is completed the projects shall use the guidance in the attached meeting minutes in items 4 and 5. 
HNF-2919

Revision 1

\section{DST Specification Section 3.3.6.3.2, Spill Prevention and Controls}

The system shall incorporate spill prevention and control design features in accordance with 40CFR264.193 and: WAC 173-303-630(7) and WAC 173-303-640(5). In the event of a conflict, the most stringent requirement shall take precedence.

Comment: No HNF-PROs address spill prevention at a detail design level. The cited WACs and CFRs do address design features to mitigate against spills.

\section{SST Specification Section 3.3.6.3.2, Spill Prevention and Controls}

The new and modified portions of the system shall incorporate spill prevention and control design features in accordance with 40CFR264.193; WAC 173-303-630(7) and WAC 173303-640(5). In the event of a conflict, the most stringent requirement shall take precedence. Existing portions of the SST system are subject to the RCRA negotiation and approval process and relevant agreements pursuant to the Tri-Party Agreement.

Comment: No HNF-PROs address spill prevention at a detail design level. The cited WACs and CFRs do address design features to mitigate against spills.

\section{DST and SST Specification Section 3.3.6.3.3, Nonradioactive Airborne Emissions}

The system shall incorporate design features that limit the combined nonradioactive ambient airborne emissions from all TWRS major facilities such that compliance with HNF-PRO 2595 Rev. $O$ is achieved. Also other Hanford Site major facilities nonradioactive airborne emissions shall be considered when designing the system to be compliant with the above requirement. Dangerous waste tank systems that may emit organic vapors are subject to the WAC 173-303-400 and 40 CFR Part 265 Subparts AA and BB for SSTs and for DSTs prior to issuance of a final permit) and to WAC 173-303-690 and 69I and 40 CFR Part 264 Subparts AA and $B B$ (for DSTs after final permit issuance).

Comment: This HNF-PRO leads the designer through the process of selecting the best or most appropriate technology to be filed with the Notice of Construction (NOC) in the permitting process.

HNF-PRO-2595, Rev. 0, Air Quality Program - Nonradioactive Emissions

DOE Order 5400.1, General Environmental Protection

WAC 173-400, General Regulations for Air Pollution Sources

BCAA, Benton Clean Air Authority

\section{DST and SST Specification Section 3.3.6.3.4, Radioactive Airborne Emissions}

The system shall incorporate design features that limit the combined radioactive ambient airborne emissions from all TWRS major facilities such that compliance with WAC 246-247 is 
HNF-2919

Revision 1

achieved. Also other Hanford Site major facilities radioactive airborne emissions shall be considered when designing the system to be compliant with the above requirement.

Comment: No HNF-PROs presently exist that leads the designer to processes, like BARCT, required in the Notice of Construction guided by WAC 246-247.

\section{DST and SST Specification Section 3.3.6.3.5, Monitoring of Liquid Effluent Discharges to the Environment}

The system shall be designed to comply with the liquid effluent monitoring requirements contained in HNF-PRO-456 Rev.0 Water Quality Program.

Comment: This HNF-PRO leads the designer through the process of selecting the best or most appropriate technology to be filed as part of the permit.

HNF-PRO-456 Rev.0 Water Quality Program.

DOE Order 5400.1, General Environmental Protection Program

DOE Order 5400.5, Radiation Protection of the Public and Environment

DOE Order 6430.1A, General Design Criteria

Seventeen WAC

Five CFR

DST and SST Specification Section 3.3.6.3.6, Radiation Protection of the Public and Environment

The system shall be designed in accordance with the radiation release limits specified in 10CFR20, 40CFR191, and WAC 246-247.

Comments/Suggestions:

No HNF-PROs were found that specify releases at the Hanford site boundary as well as the cited references.

\section{DST and SST Specification Section 3.3.7, Human Engineering}

System design shall comply with Section 1300-12, "Human factors Engineering, "of DOE 6430.1A.

Comment: HNF-PROs do not deal with this subject at a design level. Human Engineering in this context primarily deals with designing a system analyzed for and protected from "operator error." 
HNF-2919

Revision 1

\section{DST and SST Specification Section 3.3.8.1, Criticality Safety}

The system shall store, transfer, and prepare radionuclides in a manner which prevents criticality in accordance with DOE order 5480.24 and HNF-PRO-334 Rev. O Criticality Safety General Requirements.

Comments/Suggestions: DOE Order 5480.24 is the document which drives the HNF-PRO-334 that address criticality.

\section{DST and SST Specification Section 3.3.8.2, Nuclear Safety Classification}

The subsystem and components shall be designed in accordance with the safety classification for each. The safety classification shall be determined using the process described in HNF-PRO-700 Rev.1, HNF-PRO-701 Rev.0, HNF-PRO-702 Rev.0, HNF-PRO-703 Rev.0, and HNF-PRO-704 Rev.0 based on the guidelines in HNF-SD-WM-BIO-001, Tables 5.3-2 and 5.3-3 (AB).

Comments/Suggestions: none

HNF-PRO-700, Rev 1, Safety Analysis and Technical Safety Requirements

DOE 5480.21

DOE 5480.22

DOE 5480.23

DOE 5481.1B

DOE 6430.1A
Unreviewed Safety Questions.

Technical Safety Requirements. Nuclear Safety Analysis Reports. Safety Analysis and Review System. General Design Criteria.

HNF-PRO-701 Rev. 0, Safety Analysis Process - Existing Facility

DOE-STD-1082-94 Preparation, Review, and Approval of Implementation Plans for Nuclear Safety Requirements.

DOE-STD-3011-94 Guidance for Preparation of DOE 5480.22 (TSR) and DOE 5480.23

(SAR) Implementation Plans.

DOE-EM-STD-5502-94 Hazard Baseline Documentation.

HNF-PRO-702 Rev. 0, Safety Analysis Process - Facility Change or Modification

DOE 5480.21 Unreviewed Safety Questions.

DOE 5480.23 Nuclear Safety Analysis Reports.

DOE 5481.1B Safety Analysis and Review Systems.

HNF-PRO-703 Rev. 0, Safety Analysis Process - New Project

DOE 5480.21 Unreviewed Safety Questions DOE 5480.23, Nuclear Safety Analysis Reports 
DOE 5481.1B, Safety Analysis and Review Systems

DOE 6430.1A, General Design Criteria

HNF-PRO-704, Rev 0, Hazard and Accident Analysis Process

29 CFR Part 1910, "Occupational Safety and Health Standards," Section 1910.119

10 CFR Part 30, "Rules of General Applicability to Domestic Licensing of Byproduct Material

49 CFR Part 173, "Shippers--General Requirements for Shipments and Packagings

DOE 5480.23, Nuclear Safety Analysis Reports.

DOE 5481.1B, Safety Analysis and Review Systems.

DOE N 5400.9, Sealed Source Control Policy.

DOE-STD-1027-92, Hazard Categorization and Accident Analysis Techniques for Compliance with DOE Order 5480.23, Nuclear Safety Analysis Reports.

DOE-STD-3009-94, Preparation Guide for U.S. Department of Energy Nonreactor Nuclear Facility Safety Analysis Reports.

DOE-EM-STD-5502-94, Hazard Baseline Documentation.

HNF-PRO-430 Rev.1, Safety Analysis Program

DOE $5480.21 \quad$ Unreviewed Safety Questions

DOE 5480.22 Technical Safety Requirements

DOE 5480.23 Nuclear Safety Analysis Reports

DOE 6430.1A General Design Criteria

DOE STD 1027-92 Hazard Categorization and Accident Analysis Techniques for Compliance with DOE 5480.23 Nuclear Safety Analysis Reports.

DOE STD 3009-94 Preparation Guide for U.S. DOE Nonreactor Nuclear Facility safety Analysis Reports.

DOE STD 3011-94 Guide for Preparation of DOE 5480.22\&23 Implementation Plans

DOE-EM-STD-5502-94 Hazard Baseline Documentation

\section{DST and SST Specification Section 3.3.9.1, General System and Information Security}

The system shall be designed in accordance with HNF-PRO-394 Rev. 0 for general system and information security.

Comments/Suggestions: none

HNF-PRO-394 Rev.0, Physical Protection of Properties and Facilities

DOE M 5632.1C-1 Manual for Protection and Control of Safeguards and Security Interests 
HNF-2919

Revision 1

\section{DST and SST Specification Section 3.3.9.2, Radiation Area Security}

The system shall be designed such that access controls to areas of high radiation meet the requirements of DOE/RL-96-109 Rev 0 Hanford Site Radiological Control Manual (also known as HSRCM)

Comments/Suggestions: HNF-PROs do not address these specific issues. Therefore the DOE/RL-96-109 Rev 0 (HSRCM) reference is appropriate.

\section{DST and SST Specification Section 3.4, Documentation}

Records, documents, and drawing control pertinent to design functions shall be in accordance with HNF-PRO-222 Rev.0 and HNF-PRO-224 Rev.0. Drafting standards for drawings and Interface Control shall be in accordance with HNF-PRO-1819, Rev.0.

Comments/Suggestions: Only HNF-PRO-222, Rev.0, and HNF-PRO-1819 tie to PHMC Contract or MAR. The other two HNF-PROs do not tie to either the MAR or PHMC contract but provide the needed guidance/requirement and should be retained in spite of their lack of traceability.

HNF-PRO-222, Rev.0, Quality Assurance Records

HNF-PRO-224, Rev.0, Document Control

HNF-PRO-222, Quality Assurance Records.

DOE 1324.5B Records Management Program

HNF-PRO-224, Document Control

DOE-RL-CLS-HBK Hanford Site Handbook for Control of Classified Documents

HNF-PRO-1819, Rev. 0, PHMC Engineering Requirements

DOE 5480.20A, Personnel Qualification and Accreditation

DOE 5700.6C, Quality Assurance

DOE 6430.1A, General Design Criteria

DST and SST Specification Section 3.5.2, Transportation of Hazardous Materials

Support equipment used to ship hazardous materials shall be designed to comply with the requirements of HNF-PRO-156, Rev.0.

Comments/Suggestions: The driver for this HNF-PROs is DOE 5480.3 Safety Requirements for the Packaging and Transportation of Hazardous Materials, Hazardous Substances, and Hazardous Wastes. 
HNF-2919

Revision 1

HNF-PRO-156, Rev.0, Nonradioactive Hazardous Material/Waste Shipments

40CFR261

49CFR100-199

Identification and Listing of Hazardous Waste

DOE $460.1 \mathrm{~A}$

Transportation

Packaging and Transportation Safety

DOE $460.2 \mathrm{~A}$

RCRA

Departmental Materials Transportation and Packing Management

WAC 173-303

Hanford Facility RCRA Permit

Dangerous Waste Regulations

\section{DST and SST Specification Section 3.5.3.1, System-Generated Solid Waste}

The SST/DST System shall comply with the requirements of HNF-PRO-455, Rev.0, Solid Waste Management, for solid waste generated as a result of system operations and maintenance.

Comments/Suggestions: Radioactive waste is not included in this category.

HNF-PRO-455, Rev.0, Solid Waste Management.

40CFR191 Environmental Radiation Protection Standards for Management and Disposal of Spent Nuclear Fuel, High-Level and Transuranic Radioactive Wastes

40CFR241 Protection of Environment

40 CFR247-250 Protection of Environment

40CFR252-253 Protection of Environment

40CFR260

Protection of Environment

40CFR260-270

Protection of Environment

40CFR268

Land Disposal Restrictions

40CFR279

Protection of Environment

40CFR61

49CFR171-179

DOE 5400.5

DOE 5820.2A

RCW70.95.240

National Emission Standards for Hazardous Air Pollutants

Transportation

Radiation Protection of the Public and the Environment

Radioactive Waste Management

Solid Waste Management - Reduction and Recycling

WAC 173-300

Certification of Operator of Solid Waste Incinerator and Landfill

Facilities

WAC 173-303 Dangerous Waste Regulations

WAC 173-304 Minimum Functional Standards for Solid Waste Handling

WAC 246-290 Public Water Supplies 
HNF-2919

Revision 1

\section{DST and SST Specification Section 3.6, Personnel and Training}

The system shall be designed such that it can be operated by personnel possessing qualifications in accordance with HNF-PRO-057, Rev.0; HNF-PRO-065, Rev.0; HNF-PRO-068, Rev.0; HNF-PRO-071, Rev.0; HNF-PRO-082, Rev.0; HNF-PRO-153, Rev.0;HNF-PRO-161, Rev.0; HNF-PRO-166, Rev.0; and HNF-SD-WM-TR-026, Rev.5.

Comments/Suggestions: All of these tie to DOE 5480.20A, Chapter IV, which provides the designer information about the knowledge/education/skills of the people who will operate and maintain the hardware designed.

HNF-PRO-057, Rev.0, Hanford General Employee Training.

10CFR707

10CFR835

29CFR 1910

29CFR1926

DOE-RL-93-75 RCRA

DOE 1240.2A/P

DOE 1360.2B

DOE 2030.4B

DOE 3791.2A

DOE 470.1

DOE 5400.1

DOE 5480.10

DOE 5480.11

DOE 5480.19

DOE 5480.20A

DOE 5483.1A

DOE 5500.3A

DOE $5700.6 \mathrm{C}$

WAC 173-303

WAC 173-330

WAC 296-62
Workplace Substance Abuse Programs at DOE Sites

Occupational Radiation Protection

Occupational Safety and Health Standards

Safety and Health Regulation for Construction

Resource Conservation and Recovery Act

Unclassified Visits and Assignments by Foreign Nationals

Unclassified Computer Security Program

Reporting Fraud, waste, and Abuse

Federal Employee Motor Vehicle Safety

Safeguards and Security Program

General Environment Protection Program

Contractor Industrial Hygiene Program

Radiation Protection for Occupational Workers

Conduct of Operations Requirements

Personnel Qualification and Accreditation

Occupation Safety and Health Program for DOE

Planning and Preparedness for Operation Emergencies

Quality Assurance

Dangerous Waste Regulations

Used Automotive Oil Recycling Signs

Department of Labor and Industries

HNF-PRO-153, Rev.0, Nuclear Process Operator Training Program

NONE

HNF-PRO-166 Rev.0 Transportation Safety Training Requirements

DOE 460.1A Packaging and Transportation Safety

DOE 460.2A Departmental Materials Transportation and Packing Management

HNF-PRO-065 Rev.0 Environmental Training 
HNF-2919

Revision 1

DOE 5480.20A

Personnel Qualification and Accreditation

HNF-PRO-082 Rev.0 Radiological Worker Training

10CFR835 Occupational Radiation Protection

DOE 5480.11 Radiation Protection for Occupational Workers

DOE 5480.20A Personnel Qualification and Accreditation

DOE 5480.18B Nuclear Facility Training Accreditation Program

DOE/EH-256T Department of Energy Radiological Control Manual

HNF-PRO-071 Rev.0 Radiological Control Technician Training

10CFR835 Occupational Radiation Protection

DOE $5480.11 \quad$ Radiation Protection for Occupational Workers

DOE 5480.20A Personnel Qualification and Accreditation

DOE 5480.18B Nuclear Facility Training Accreditation Program

DOE/EH-256T Department of Energy Radiological Control Manual

HNF-PRO-161 Rev.0 Criticality Safety Training

10CFR835 Occupational Radiation Protection

DOE 5480.20A Personnel Qualification and Accreditation

HNF-PRO-068 Rev.0 Site Maintenance Training

DOE 4330.4A

DOE 5480.19

DOE 5480.20
Maintenance Management Program

Conduct of Operation

Personnel Selection, Qualification, Training, and Staffing

Requirements at DOE Reactor and Non-Reactor Facilities

\section{DST and SST Specification Section 3.9, Qualification}

The system design shall be verified to HNF-PRO-1819, Rev.0. 
HNF-2919

Revision 1

HNF-PRO-1819, Rev. 0, PHMC Engineering Requirements

DOE 5480.20A, Personnel Qualification and Accreditation

DOE 5700.6C, Quality Assurance

DOE 6430.1A, General Design Criteria

Comments/Suggestions: This HNF-PRO provides guidance to specify specific qualification testing and/or test conditions for system qualification. 
HNF-2919

Revision 1

APPENDIX A

\section{TRACEABILITY}

Hard copies of the selected HNF-PROs were reviewed and traced for applicability to a particular section in the DST and SST Specifications. Likewise, each of the selected WACs, CFRs, and DOE Orders were read for applicability to specific sections of the DST Specification. Many additional HNF-PROs were reviewed for use in the DST and SST Specifications and found not to include the type of information needed.

This appendix includes a list of the HNF-PROs used in the DST and SST Specifications and how they can be traced to the PHMC Contract and the Mission Analysis Report (MAR).

This listing of HNF-PRO traceability is electronic only. Only the tie between the documents has been established, the exact "chapter and verse" in the higher level reference has not been tied to the HNF-PRO electronically for its applicability. Applicability of HNF-PROs was established by reading a hardcopy.

HNF-PRO-057, Rev 0, Hanford General Employee Training -

MAR: $\quad$ 10CFR835:

PHMC: $\quad$ DOE 5480.11, 5480.20A, 5480.19, 5480.10, 5483.1A, 5700.6C

3.6 Personnel and Training

HNF-PRO-065, Rev 0, Environmental Training -

MAR: none

PHMC: $\quad 5480.20 \mathrm{~A}$

3.6 Personnel and Training

HNF-PRO-068, Rev 0, Site Maintenance Training -

MAR: none

PHMC: DOE 5480.1

3.6 Personnel and Training

HNF-PRO-071, Rev 0, Radiological Control Technician Training -

MAR: $\quad$ 10CFR835

PHMC: DOE 5480.11, 5480.20A

3.6 PERSONNEL AND TRAINING

HNF-PRO-082, Rev 0, Radiological Worker Training - 
MAR: none

PHMC: DOE 5480.1I, 5480.20A

3.6 PERSONNEL AND TRAINING

HNF-PRO-97 Rev 0, Engineering Design and Evaluation -

MAR: none

PHMC: $\quad$ DOE 5480.23, 5481.1B, 5480.28

3.2.6.1 Environmental Conditions

HNF-PRO-153, Rev 0, Nuclear Process Operator Training Program -

MAR: none

PHMC: $\quad$ 5480.20A, DOE 5480.19

3.6 PERSONNEL AND TRAINING

HNF-PRO-156, Rev. 0, Nonradioactive Hazardous Materials/Hazardous Waste (HM/HW) Shipments

MAR: WAC 173-303

PHMC: none

3.5.2 Transportation of Hazardous Materials

HNF-PRO-157, Rev 0, Radicactive Material/Waste Shipments -

MAR: $\quad$ WAC 173-303

PHMC: $\quad$ DOE 5400.5, 5480.3, 1540.2, 5700.6C

3.2.7 Transportability

HNF-PRO-161, Rev 0, Criticality Safety Training Program Description -

MAR: $\quad$ 10CFR835

PHMC: $\quad 5480.20 \mathrm{~A}$

3.5.2 Transportation of Hazardous Materials

3.6 PERSONNEL AND TRAINING

HNF-PRO-166 Rev.0 Transportation Safety Training Requirements

MAR: none

PHMC: DOE 5480.3

3.6 PERSONNEL AND TRAINING

HNF-PRO-222 Rev,0, Quality Assurance Records -

MAR none

PHMC: DOE 1324.5B

3.4 DOCUMENTATION

HNF-PRO-334 Rev.0, Criticality Safety General Requirements -

MAR: none

PHMC: $\quad$ DOE 5480.24

3.3.8.1 Criticality Safety 
HNF-2919

Revision 1

HNF-PRO-349 Rev 0, Fire Protection Design Criteria

PHMC DOE 6430.1A, DOE 5480.7A

3.3.6.2.5 Fire Protection

HNF-PRO-394 Rev.0, Physical Protection of Properties and Facilities -

MAR: none

PHMC: DOE 5632.1C

3.3.9.1 General System and Information Security

HNF-PRO-430, Rev. 1, Safety Analysis Program -

MAR: none

PHMC: $\quad$ DOE 5480.23, 5480.22, 5480.21, 5481.1B, 6430.1A

3.3.8.2 Nuclear Safety Classification

HNF-PRO-451, Rev. 0, Regulated Substance Management -

MAR: $\quad$ 10CFR61, 40CFR61, 40CFR761, 29CFR1910, WAC 173-303, WAC $173-360$

PHMC: DOE 6430.1A

3.3.1.1 Toxic Products and Formulations

HNF-PRO-455, Rev 0, Solid Waste Management -

MAR: $\quad$ 10CFR61, 40CFR61, 40CFR191, 40CFR265, 40CFR268, 40CFR279,

WAC 173-303, DOE 5820.2A

PHMC: DOE 5400.5

3.5.3.1 Solid Waste Acceptance Criteria

HNF-PRO-456 Rev.0 Water Quality Program

MAR: $\quad$ DOE $5400.1,5400.5$

PHMC: DOE 5400.1, 5400.5, 6430.1A

3.2.8 Flexibility and Expansion

3.3.6.3.5 Monitoring of Liquid Effluent Discharges to the Environment

HNF-PR0-500 Rev.0, Operations Security

MAR: none

PHMC: DOE 471.2A, 1240.2B

3.3.9.1 General System and Information Security

HNF-PRO-537 Rev.0, Criticality Safety Control of Fissionable Material -

MAR: none

PHMC: DOE 5480.24

3.3.8.1 Criticality Safety

HNF-PRO-539, Rev 0, Criticality Safety Evaluations -

MAR: none

PHMC: $\quad$ DOE $5480.23,5480.24$ 
3.3.8.1 Criticality Safety

HNF-PRO-543 Rev.0, Fissionable Material Storage -

MAR: none

PHMC: DOE 5480.24

3.3.8.1 Criticality Safety

HNF-PRO-546 Rev.0, Criticality Alarm System

MAR: none

PHMC: DOE 5480.24

3.3.8.1 Criticality Safety

HNF-PRO-700, Rev 1, Safety Analysis and Technical Safety Requirements

MAR: none

PHMC: $\quad$ DOE $5480.23,5480.22,5480.21,5481.1 \mathrm{~B}, 6430.1 \mathrm{~A}$

3.3.8.2 Nuclear Safety Classification

HNF-PRO-701 Rev. 0, Safety Analysis Process - Existing Facility

MAR: none

PHMC: $\quad$ DOE 5480.23, 5480.22, 5480.21, 5481.1B, 6430.1A

3.3.8.2 Nuclear Safety Classification

HNF-PRO-702 Rev. 0, Safety Analysis Process - Facility Change or Modification

MAR: none

PHMC: DOE 5480.23

3.3.8.2 Nuclear Safety Classification

HNF-PRO-703 Rev. 0, Safety Analysis Process - New Project

MAR: none

PHMC: $\quad$ DOE 5480.23, 5480.21, 5481.1B, 6430.1A

3.3.8.2 Nuclear Safety Classification

HNF-PRO-704, Rev.0, Hazard and Accident Analysis Process

MAR: $\quad$ 29CFR1910

PHMC: $\quad$ DOE $5480.23,5481.1 \mathrm{~B}$

3.3.8.2 Nuclear Safety Classification

HNF-PRO-1629, Rev 0, ALARA Administrative Control Levels -

MAR: $\quad$ 10CFR835

PHMC: none

3.3.6.3.6 Radiation Protection of the Public and Environment 
HNF-2919

Revision 1

HNF-PRO-1819, Rev. 0, PHMC Engineering Requirements

MAR: None

PHMC: $\quad$ DOE 5480.20A, 5700.6C, 6430.1A

3.9 Qualification

HNF-PRO-2595, Rev 0, Air Quality Program - Nonradioactive Emissions

MAR: $\quad$ DOE 5400.1

PHMC: $\quad$ DOE 5400.1

3.3.6.3.3 Nonradioactive Airborne Emissions

DST/SST Specification HNF-PROs that DO NOT trace to MAR or PHMC Contract

HNF-PRO-224 Rev0, Document Control -

3.4 Documentation

Full titles of MAR constraints/references:

40 CFR 268- Land Disposal Restrictions

29 CFR 1910 Occupational Safety and Health Standards

10 CFR 61 - Licensing Requirements for Land Disposal of Radioactive Waste

40 CFR 61 - National Emission Standards for Hazardous Air Pollutants

10 CFR 835 Occupational Radiation Protection

40 CFR 191 - Environmental Radiation Protection Standards for Management and Disposal of Spent Nuclear Fuel, High-Level and Transuranic

40 CFR 279. Standards of the Management of Used Oil

40 CFR 761 - Polychlorinated Biphenyls (PCBs), Manufacturing, Processing, Distribution in Commerce, and Use Prohibitions

40 CFR 265- Interim Status Standards for Owners and Operators of Hazardous Waste

Treatment, Storage, and Disposal Facilities

WAC 173-303 Dangerous waste regulations.

WAC 173-360 Underground storage tank regulations.

DOE-5820.2A/P -RADIOACTIVE WASTE MANAGEMENT

DOE 4330.4B - MAINTENANCE MANAGEMENT PROGRAM

DOE-5480.19/P -CONDUCT OF OPERATIONS REQUIREMENTS FOR

DOE FACILITIES

DOE-5480.20A/P -PERSONNEL SELECTION, QUALIFICATION, AND

TRAINING

DOE-5400.5/P -RADIATION PROTECTION OF THE PUBLIC AND THE

ENVIRONMENT 
HNF-2919

Revision 1

DOE-5633.3B/P -CONTROL AND ACCOUNTABILITY OF NUCLEAR MATERIALS

DOE-5400.1/P -GENERAL ENVIRONMENTAL PROTECTION PROGRAM

DOE-5480.21/P -UNREVIEWED SAFETY QUESTIONS

DOE-5480.23/P -NUCLEAR SAFETY ANAL YSIS REPORTS

DOE-5632.1C/P -PROTECTION AND CONTROL OF SAFEGUARDS

AND SECURITY

(all of these DOE orders are listed in the PHMC contract) 
HNF-2919

Revision 1

APPENDIX B

MEETING MINUTES--

LEAK-RELATED REQUIREMENTS 
HNF-2919

Revision 1

This page intentionally left blank. 


\section{Mecting Minutes}

Subject: Leak-Related Requirements

To:

Distribution

From:

M. A. deLamare

Department - Operation-Component

Retrieval Engineering

\begin{tabular}{|c|c|c|c|}
\hline \multicolumn{4}{|c|}{ Distribution } \\
\hline Name & MSIN & Name & MSIN \\
\hline A. F. Choho & R3-73 & J. A. Reeves* & R3-75 \\
\hline T. J. Conrads* & $\mathrm{R} 3 \cdot 73$ & W. J. Stokes & R3-75 \\
\hline M. A. deLamare* & $\bar{R} 3-73$ & W. T. Thompson* & R3-73 \\
\hline G. C. DeWeese & R3.73 & R. L. Treat* & R3-75 \\
\hline D. F. Iwatate* & R2-89 & & \\
\hline & & *attendees & \\
\hline
\end{tabular}

1. All were agreed that our positions on leak-related requirements and on the C-104 retrieval strategy need to be coordinated within the PHMC, RL, and Ecology early in the Project W-523 lifecycle. (During conceptual phase.)

2. All were agreed that the C-104 strategy depart from the previous ALV strategy to a "best" proven, cost-effective, etc., strategy. The "best" approach would evaluated and selected using the TWRS Alternatives Generation and Analysis (AGA) and decision management process. Selection criteria would be set in the approved decision plan.

3. All agreed that a predetermined response to a detected leak should be established. It is not acceptable to wait until a leak is detected to form a response. I believe the response should be determined during conceptual phase. This enables the project to provide everything needed to implement the response.

4. Homework assignment from the meeting was to review and markup the requirements below. The resulting requirements will be input to the single-shell tank (SST) system specification.

The system shall utilize best-proven and cost-effective retrieval technologies that balance system performance with the risk of waste leakage from SST tanks.

The system shall utilize proven and cost -effective leak detection, monitoring and mitigation technologies.

5. Item 3 and above started the thought process that maybe a third requirement is needed. Again, verification of compliance would be via the AGA/decision processes. Please provide me your thoughts on this one as well.

The system shall have the capability to stop retrieval operations when a leak in the tank is detected, and place that tank-in condition that reduces the risk of further leakage.

Note: I think the threshold to cease operations would not go into the Level I Specification, but be placed in an operational specification.

6. One final thought. It may be a good idea if we were to calculate ALVs for C-104 and C-102 to determine where the cutoff thresholds should be set. Who could perform this calculation? How long would it take? 


\begin{tabular}{|c|c|c|c|c|c|}
\hline \multicolumn{6}{|c|}{ DISTRIBUTION SHEET } \\
\hline To & \multirow{2}{*}{$\begin{array}{l}\text { From } \\
\text { C. P. Shaw }\end{array}$} & & & \multicolumn{2}{|l|}{ Page 1 of 1} \\
\hline Distribution & & & & \multicolumn{2}{|c|}{ Date $3 / 15 / 99$} \\
\hline \multicolumn{4}{|l|}{ Project Title/Work Order } & \multicolumn{2}{|l|}{ EDT No. } \\
\hline \multicolumn{4}{|c|}{$\begin{array}{l}\text { Constraints for System Specifications for the Double-Shell and } \\
\text { Single-Shell Tank Systems, HNF-2919, Rev. } 1\end{array}$} & \multicolumn{2}{|c|}{ ECN No. 644467} \\
\hline Name & MSIN & $\begin{array}{l}\text { Text } \\
\text { With All } \\
\text { Attach. }\end{array}$ & Text Only & $\begin{array}{l}\text { Attach./ } \\
\text { Appendix } \\
\text { Only }\end{array}$ & $\begin{array}{l}\text { EDT/ECN } \\
\text { Only }\end{array}$ \\
\hline $\begin{array}{l}\text { Central Files } \\
\text { DOE Public Reading Room } \\
\text { DIMC }\end{array}$ & $\begin{array}{l}B 1-07 \\
H 2-53 \\
R 1-41\end{array}$ & $\begin{array}{l}X \\
X \\
X\end{array}$ & & & \\
\hline $\begin{array}{l}\text { C. D. Acree } \\
\text { S. K. Baker } \\
\text { A. F. Choho } \\
\text { R. D. Claghorn } \\
\text { T. J. Conrads } \\
\text { M. A. Delamare } \\
\text { C. E. Grenard } \\
\text { M. W. Leonard } \\
\text { S. M. O'Toole } \\
\text { R. D. Potter } \\
\text { C. P. Shaw }\end{array}$ & $\begin{array}{l}\text { R2-89 } \\
\text { R3-73 } \\
\text { R3-73 } \\
\text { R3-73 } \\
\text { R3-73 } \\
\text { B1-45 } \\
\text { R3-74 } \\
\text { B1-45 } \\
\text { R2-89 } \\
\text { R3-73 } \\
\text { R3-74 }\end{array}$ & $\begin{array}{l}X \\
X \\
X \\
X \\
X \\
X \\
X \\
X \\
X \\
X \\
X\end{array}$ & & & \\
\hline
\end{tabular}

